7. Політологія : навчальний енциклопедичний словник довідник для студентів BHЗ I-IV рівнів акредитації / За наук. ред. д-ра політ. н. Хоми Н. М. [В. М. Денисенко, О. М. Сорба, Л. Я. Угрин та ін.]. - Львів : «Новий Світ 2000», 2014. - 779 c.

8. Почепцов Г. Г. Стратегический анализ. Стратегический анализ для политики, бизнеса и военного дела / Георгий Георгиевич Почепцов. - К. : Дзвін, 2004 - 333 с.

9. Сунь-Цзы. Искусство войны [Електронний ресурс] / Сунь-Цзы ; пер. Н. Конрада. - Режим доступу : http://librebook.me/the_art_of_war

10. Туронок С. Г. Політичнй аналіз і прогнозування [Електронний ресурс] / Станіслав Генріхович Туронок. - Режим доступу : https://stud.com.ua/43949/politologiya/politichniy_analiz_i_prognozuvannya

11. Steiner G. A. Strategic Planning [Електронний ресурс] / George A. Steiner. - NY : Simon and Schuster, 2010. - 400 с. - Режим доступу : https://books.google.com.ua/books?id=EXoPC22vb4oC \&printsec=frontcover\&hl= $\mathrm{ru} \# \mathrm{v}=$ onepage $\& \mathrm{q} \& \mathrm{f}=$ false

DOI 10.31558/2617-0248.2018.3.7

УДК 327.7

\title{
ТИМЧАСОВА АДМІНІСТРАЦІЯ ООН ЯК ПЕРШИЙ ЕТАП ДЕРЖАВНОГО БУДІВНИЦТВА
}

\section{Стойко О. М., д. політ. н., Інститут держави і права ім. В.М. Корецького НАН України}

Проаналізовано досвід і наслідки впровадження тимчасової адміністрації у рамках миротворчих операцій ООН. У Камбоджі основним завданням тимчасової адміністрації, створеної резолюцією РБ ООН у 1992 році, було проведення виборів, за результатом яких відбулася зміна державного ладу країни та припинено тривалу громадянську війну.

У Хорватії запровадження тимчасової адміністрації в 1995 році було передбачено мирною угодою між урядом та представниками сербів, які брали участь у створенні самопроголошеної Республіки Сербська Країна, для контролю за процесом демілітаризації та реалізації плану з мирної реінтеграції регіону. Миротворча місія була успішно завершена в 1998 році без зміни державних кордонів.

Фактичне звільнення території Косово від армії Югославії у результаті військової операції НАТО в 1999 році дало змогу РБ ООН прийняти резолюцію про тимчасову адміністрацію, що мала забезпечити безпеку, стабільність, дотримання прав людини та сприяти формуванню основних інститутів держави. Після проголошення незалежності у 2008 році мандат миротворчої місії було змінено, однак територія і надалі залишається потенційним джерелом нестабільності у регіоні.

Створена в 1999 році тимчасова адміністрація у Східному Тиморі спряла реалізації результатів референдуму, на якому більшість мешканців проголосувала за відділення від Індонезії. Виникнення нової держави у 2002 році зумовило зміни у мандаті миротворчої місії, яка у різних формах тривала до 2012 року.

Спільними для останніх трьох випадків є наявність цивільної (адміністративної) та військової (силової) складових у миротворчій операції ООН. Встановлено, що діяльність такого органу на території окремих регіонів країни, що не контролюються урядом, неминуче призводить до створення нових держав та втрати територіальної цілісності, що не відповідає інтересам України при врегулюванні конфлікту на Донбасі.

Ключові слова: тимчасова адміністрація, миротворча операція, територіальна цілісність, право народів на самовизначення.

Stoyko O. M. UN transitional administration as the first stage of state building

The experience and implications of the introduction of the transitional administration within the framework of UN peacekeeping operations have been analyzed. In Cambodia, the main task of the transitional administration, established by the UN Security Council resolution in 1992, was the holding of election, which resulted in a change in the state structure and the end of a long civil war.

In Croatia, the introduction of the transitional administration in 1995 was foreseen by a peace agreement between the government and representatives of the Serbs who participated in the creation of the selfproclaimed Republic of Serbian Krajina, to monitor the process of demilitarization and to implement the plan for the peaceful reintegration of the region. The peacekeeping mission was successfully completed in 1998 without changing the state borders.

The actual liberation of Kosovo's territory from the Yugoslav Army as a result of NATO's military operation in 1999 allowed the UN Security Council to adopt a resolution on a transitional administration that was supposed to ensure security, stability, human rights and promote the formation of the main institutions of the state. After the declaration of independence in 2008, the mandate of the peacekeeping mission has been changed, but the territory remains a potential source of instability in the region. 
Established in 1999, the transitional administration in East Timor contributed to the implementation of the results of the referendum, in which the majority of the residents voted for separation from Indonesia. The emergence of a new state in 2002 led to changes in the mandate of a peacekeeping mission, which lasted until 2012 in various forms.

Common for the last three cases is the presence of civil (administrative) and military (force) components in the UN peacekeeping operation. It is established that the activity of such an authority in the territory of certain regions of the country, which is not controlled by the government, inevitably leads to the creation of new states and the loss of territorial integrity, which is not in the interests of Ukraine in resolving the conflict in Donbass.

Key words: transitional administration, peacekeeping operation, territorial integrity, right of peoples to selfdetermination.

У вересні 2018 року у зв'язку з можливістю введення миротворчої місії ООН для врегулювання ситуації на Донбасі пролунала думка про необхідність ії доповнення не лише військовим компонентом, а й міжнародною (тимчасовою) адміністрацією. Однак, навіть без урахування проблем, зумовлених легалізацією такого управлінського органу в законодавстві України, тимчасова адміністрація, особливо якщо вона запроваджена в окремих районах, як свідчить досвід інших країн, призводить радше до відділення конфліктних регіонів, дезінтеграції ніж до відновлення територіальної цілісності держави. Метою статті є аналіз діяльності тимчасових адміністрацій під егідою ООН та визначення доцільності застосування такого інструменту миротворчості в Україні.

Перший випадок введення ООН тимчасової адміністрації (ТА) датується 1992 роком, коли Рада Безпеки та уряд Камбоджі домовилися про створення такого органу для реалізації Паризьких мирних угод 1991 року, які завершили тривалий збройний конфлікт між пров'єтнамськи налаштованим урядом країни та представниками політичної опозиції. Основними ії завданнями було відновлення миру і формування нового керівництва країною шляхом проведення вільних і чесних виборів, прийняття нової конституції. До формування демократично обраних органів державної влади ТА ООН здійснювала нагляд за всіма аспектами державного управління, включаючи зовнішню політику, національну оборону, фінанси тощо. Завдяки такому посередництву у 1993 році було відновлено Королівство Камбоджа, яке було визнано ООН.

У 1995 році ООН вдалася до подібного експерименту в Хорватії, результатом чого стало відновлення територіальної цілісності країни та зміцнення іiі суверенітету над своєю територією. Однак дві останніх тимчасових адміністрації, започатковані в 1999 році у Косово та Східному Тиморі призвели до виникнення нових держав на політичній карті світу. Вихідні умови у цих трьох країнах є досить схожими до ситуації в Україні - втрата урядом контролю над частиною території держави, тому потребують детальнішого вивчення.

Хорватії у травні та серпні 1995 року вдалося провести успішні військові операції - «Блискавка» і «Буря», в ході якої збройним силам країни та поліції вдалося відвоювати більшість території країни, що ввійшла до складу самопроголошеної Республіки Сербська Країна (1991-1995). Долю решти частини невизнаної республіки вздовж Дунаю - Східної Славонії, Бараня, Західного Срема - вирішила Ердутська угода, що в документах ООН проходить як Основна угода, підписана 12 листопада 1995 року представниками Хорватії та місцевою сербською владою. Вона містила 14 пунктів, що передбачали у тому числі: 1) звернення до РБ ООН з проханням створити тимчасову адміністрацію (ТА), що здійснюватиме управління регіоном у перехідний період в інтересах всіх осіб, які проживають в регіоні, або тих, хто до нього повертається; 2) прохання до РБ ООН розгорнути на цей період міжнародні сили для підтримки миру і безпеки в регіоні або ж іншим способом сприяти реалізації угоди; 3) організацію і проведення ТА виборів до всіх місцевих органів управління, включаючи муніципальні, районні та окружні, а також забезпечення сербській громаді права призначити об'єднану раду муніципалітетів.

На виконання положень мирної угоди Радбез прийняв рішення про Тимчасову адміністрацію ООН для Східної Славонії, Бараня та Західного Срема (ТАООНСС, United Nations Transitional authority in Eastern Slavonia, Barnaja and Western Sirmium, UNTAES ) [5]. Місія розпочалася 15 січня 1996 року, а до ії завдань входило стеження за демілітаризацією цих районів та забезпечення мирної реінтеграції території до складу Хорватії. Через рік мандат було продовжено ще на один рік і ТА припинила свою діяльність 15 січня 1998 року, однак група підтримки зі 180 співробітників цивільної поліції $\mathrm{OOH}$ залишилася для стеження за діяльністю хорватської поліції та контролем повернення біженців.

Військовий компонент на початковому етапі налічував не більше 500 осіб, до обов'язків яких входило: здійснювати спостереження за демілітаризацією, що проводиться сторонами учасницями Основної угоди, відповідно до графіка і процедур; стежити за добровільним і безпечним поверненням біженців і переміщених осіб в початкові місця їх проживання.

Цивільна складова орієнтувалася на вирішення таких завдань: створити у найкоротші терміни тимчасові поліцейські сили, визначити їх структуру та чисельність, розробити програми навчання і контроль за ії здійсненням і нагляд за поводженням 3 правопорушниками й пенітенціарною системою; виконувати завдання, пов'язані 3 цивільною адміністрацією; організовувати вибори, надавати сприяння в їх проведенні й посвідчувати дійсність результатів виборів тощо.

Місія також здійснювала контроль за виконанням сторонами їх зобов'язань, передбачених в Основній угоді, щодо дотримання найвищих стандартів прав людини й основних свобод, сприяла формуванню атмосфери довіри між усіма місцевими жителями незалежно від їх етнічної приналежності, стежила за розмінуванням території в межах району та здійснювала активну діяльність у зв'язках з громадськістю. При цьому держави-члени, самостійно 
чи за допомогою регіональних організацій чи угод, на прохання ТАООНСС могли вживати необхідних заходів, у тому числі й авіаційну підтримку, для захисту місії і сприяти, за необхідності, іiі виводу.

1 травня 1997 року президент Хорватії Ф. Туджман оголосив про створення Державної комісії зі встановлення конституційно-правового порядку Республіки Хорватії у придунайському районі, що перебувавав під управлінням ТАООНСС, яку очолив міністр розвитку та реконструкції. Державна комісія співпрацювала 3 ТАООНСС для координації та нагляду за діяльністю всіх управлінських органів (повітів та міст), яка стосувалася мирної реінтеграції Східної Славонії, Бараня та Західного Срему в Хорватію. У нових муніципалітетах була переглянута організаційна структура з акцентуванням уваги на поверненні та правах людини, щоб контролювати виконання Основної угоди та інших гарантій та зобов'язань Хорватії.

При цьому станом на вересень 1997 року ООН була незадоволена тим, як Хорватія виконує свої зобов'язання і висловлювала побоювання щодо можливості передачі виконавчої влади в регіоні після завершення мандату [1]. РБ закликала уряд країни негайно ліквідувати усі адміністративні та правові перешкоди для двостороннього повернення переміщених осіб та біженців; забезпечити безпеку, соціальні та економічні можливості, включаючи право власності для усіх осіб, які повернулися; запобігти залякуванню поверненців та створити ефективні органи місцевого самоврядування. РБ вимагала від Хорватії забезпечити регулярні виплати пенсій та соціальної допомоги; забезпечити подальшу економічну інтеграцію; припинити нападки на етнічні групи у ЗМІ; повною мірою виконати закон про амністію та співпрацювати з Міжнародним трибуналом щодо колишньої Югославії.

Представники ООН також констатували диспропорцію у представництві сербів у судових органах, зокрема на керівних посадах. Миротворці також констатували відсутність в уряду Хорватії єдиної економічної політики, орієнтованої на інтеграцію регіону. Уряд країни не вжив жодних заходів для розгортання загальнонаціональної програми національного примирення згідно з положеннями резолюції Радбезу. Незадовільним визнано і виконання Хорватією закону про амністію, хоча уряд і заявив, що більше не веде списку військових злочинців. Водночас і представники сербської меншини не повною мірою користувалися наданими їм правами, а у деяких сферах навіть гальмували процеси реінтеграції.

Місія завершила свою роботу в січні 1998 році згідно з резолюцією Радбезу [2]. Особливістю тимчасової адміністрації у Хорватії було те, що їй вдалося зберегти територіальну цілісність держави, оскільки обидві конфліктуючі сторони погодилися на таке втручання ООН.

У Косово події розгорталися за принципово іншим сценарієм. У лютому 1998 року Армія визволення Косово, що складалася з етнічних албанців, розпочала збройне протистояння з югославською поліцією та армією 3 метою отримання незалежності. У відповідь уряд Югославії почав репресії проти мирного населення регіону, що спровокувало гуманітарну катастрофу та бомбардування території Югославії авіацією НАТО 24 березня - 10 червня 1999 року. У результаті війська Югославії залишили територію краю, який перейшов під контроль сил НАТО.

Рада Безпеки виявилася неспроможною запобігти численним людським жертвам, оскільки Російська Федерація як постійний член Ради блокувала будь-які спроби прийняти резолюцію, яка б вимагала від Югославії припинити етнічні чистки та вивести збройні сили з території Косово. Лише після фактичного звільнення території Косово від армії Югославії Рада Безпеки в своїй резолюції 1244 від 10 червня 1999 року [4] уповноважила Генерального секретаря заснувати міжнародну цивільну присутність - Місію Організації Об'єднаних Націй у справах тимчасової адміністрації в Косово (МООНТАК, United Nations Interim Administration Mission in Kosovo, UNMIK) - 3 метою створення тимчасової адміністрації для Косово, під керуванням якої населення Косово зможе користуватися істотною автономією. Ї̈̈ завдання було безпрецедентним за складністю і масштабами: Рада безпеки наділила МООНТАК повноваженнями щодо території та населення Косово, в тому числі всіма законодавчими та виконавчими повноваженнями і повноваженнями з управління судовою системою.

Першочергові завдання місії полягали у сприянні забезпеченню безпеки, стабільності та поваги прав людини в Косово і в регіоні. МООНТАК також підтримувала конструктивну взаємодію з Приштиною і Белградом, усіма громадами в Косово і регіональними і міжнародними суб'єктами.

Місію очолював Спецпредставник Генсека, який призначається Генсеком у консультаціях з Радбезом. Він уповноважений здійснювати загальне управління місією. Координувати діяльність усіх установ ООН та інших організацій, що діють у складі МООНТАК. До компонентів місії (відповідальна організація) входили такі питання як: 1) тимчасова цивільна адміністрація $(\mathrm{OOH}) ; 2)$ гуманітарні питання (Управління Верховного комісара ООН у справах біженців); 3) інституційний розвиток (ОБСЄ); 4) відновлення (Євросоюз).

Тимчасова цивільна адміністрація складалася з трьох підрозділів: Комісара поліції, Відділу 3 цивільних питань і Відділу з судових питань. Персонал Комісара поліції включав: 1) відділ міжнародної цивільної поліції за наглядом за діяльність громадянської поліції та створення косовських поліційних сил і здійснення керівництва ними; 2) відділ спеціальної поліції для забезпечення підтримки порядку і виконання інших спеціальних поліцейських функцій; 3) відділ міжнародної прикордонної поліції. Відділ з цивільних питань здійснював нагляд і, за необхідності, виконував низку цивільних функцій у таких сферах як державна служба, економічні та бюджетні питання, а також підтримка відновленню і надання соціальних послуг на перших етапах, таких як охорона здоров'я, освіта, житлово-комунальна сфера, транспорт і зв'язок.

Згодом було створено Перехідну раду Косово (ПРК), що збиралася щотижня під керівництвом Спецпредставника. Вона об'єднала усі основні політичні партії та етнічні групи, завдяки чому мешканці Косово могли безпосередньо впливати на процес прийняття МООНТАК рішень і сприяти досягненню згоди 3 широкого кола питань, пов'язаних $з$ цивільною адміністрацією, організаційною будовою та наданням основних послуг.

МООНТАК одночасно вирішувала два складних завдання: вести підготовку до здійснення тимчасової адміністрації та вживати надзвичайних заходів щодо відновлення системи надання основних послуг. 
25 липня 1999 року Спеціальний представник Генсека ООН Б. Кушнер прийняв перше розпорядження «Про органи тимчасової адміністрації у Косово», у якому зазначалося, що усі законодавчі й виконавчі функції щодо Косово, включаючи функції здійснення правосуддя, покладаються на МООНТАК i здійснюються Спецпредставником. Він міг призначити та звільнити будь-яку особу для виконання функцій у складі цивільної адміністрації. Наступне розпорядження стосувалося запобігання доступу окремих осіб та їх видалення 3 метою забезпечення громадського спокою та порядку. Третім кроком стало створення митної та інших суміжних служб у Косово. Пізніше з'явилися розпорядження про: валюту; створення суду останньої інстанції ad hoc та прокуратури аd hос; структуру і управління справами судової системи і прокурорської служби.

17 лютого 2008 року Асамблея Косово проголосувала за незалежність країни, яку визнали близько 60\% країн світу. Україна, Греція, Іспанія, Кіпр, Румунія і Словаччина утрималися від визнання. Тобто, у даному випадку хоча миротворча місія ООН та спроба державного будівництва виявилася успішною, однак має неоднозначні наслідки для системи міжнародних відносин.

У 1999 році у Східному Тиморі, що входив до складу Індонезії, був проведений референдум за сприяння політичної місії ООН в регіоні (червень-жовтень 1999 року), на якому понад 78\% підтримало рішення про незалежність, що зумовило черговий виток насильства та введення миротворчого контингенту та тимчасової адміністрації для сприяння формуванню нової держави.

Резолюція РБ [3] від 25 жовтня 1999 року заклала основи для Тимчасової адміністрації ООН в Східному Тиморі (ТАOOHCT, United Nations Transitional Administration in East Timor, UNTAET), яка мала нести спільну відповідальність за адміністративне управління в Східному Тиморі. Для цього ії наділено всіма законодавчими та виконавчими повноваженнями, включаючи здійснення правосуддя. Мандат ТА складався з: 1) забезпечення безпеки і підтримання правопорядку на всій території Східного Тимору; 2) створення ефективної адміністрації; 3) надання допомоги у розвитку цивільних і соціальних служб; 4) забезпечення координації та надання гуманітарної допомоги та допомозі в цілях відновлення і розвитку; 5) надання підтримки у створенні можливостей для самоврядування; 6) надання сприяння в створенні умов для сталого розвитку.

Основні компоненти ТАООНСТ: а) компонент управління і державної адміністрації, що включав міжнародний поліцейський елемент чисельністю до 1640 осіб; б) компонент гуманітарної допомоги та відновлення після надзвичайних ситуацій; в) військовий компонент чисельністю до 8950 військовослужбовців і до 200 військових спостерігачів.

Тимчасовим адміністратором був Спецпредставник, який відповідав за усі аспекти роботи ООН у Східному Тиморі і мав повноваження приймати нові, змінювати або скасовувати чинні закони або ж припиняти їх дію.

Резолюція поклала відповідальність на уряд Індонезії за прийняття негайних і ефективних заходів щодо забезпечення безпечного повернення біженців із Західного Тимору і інших районів Індонезії в Східний Тимор, за безпеку біженців і цивільний і гуманітарний характер таборів і поселень біженців, зокрема шляхом припинення там насильницької діяльності воєнізованих угруповань.

Також було створено Цільовий фонд, кошти якого використовувалися на відновлення основної інфраструктури, включаючи створення базових установ, функціонування державних служб і підприємств комунального господарства, і на видачу заробітної плати місцевим цивільним службовцям. Мандат місія отримала одразу на рік - до 31 січня 2001 року, а пізніше була продовжена до травня 2002 року.

Східний Тімор отримав незалежність 20 травня 2002 року, що ознаменувало закінчення трирічного процесу переходу до незалежності під керівництвом ООН. На той день Радбез запровадив нову місію з підтримки Східного Тимору - MOОНПСТ (United Nations Mission of Support in East Timor (UNMISET)), щоб надати допомогу країні до повної передачі усіх функцій новому уряду. Цей мандат був успішно завершений 20 травня 2005 року.

Отже, у випадку Камбоджі тимчасова адміністрація діяла на території усієї країни і допомогла припинити громадянську війну, зберігши державні кордони незмінними. У Хорватії учасники конфлікту самі домовилися про необхідність участі третьої сторони в особі ООН для остаточної реінтеграції регіону, що уже перебував під контролем хорватських збройних сил, а резолюція Радбезу лише заклала правову основу для відновлення територіальної цілісності держави. 3 огляду на відсутність прогресу в реалізації Мінських угод, повну залежність керівництва самопроголошених республік на Донбасі від позиції Російської Федерації, введення тимчасової адміністрації за хорватським сценарієм в Україні неможливе. У випадку Косова та Східного Тімору міжнародна спільнота поставила право народів на самовизначення вище принципу територіальної цілісності держави, а тимчасові адміністрації, створені резолюціями РБ ООН, стали першим кроком на шляху формування нових держав. Їх виникнення лише до певної міри дало змогу вирішити проблеми, що лежали в основі збройного протистояння, оскільки і до сьогодні у них фіксуються спорадичні спалахи насильства. Іншими словами, одностороннє (без згоди усіх учасників конфлікту) введення тимчасової адміністрації у регіонах, що не контролюються урядом, неминуче веде до втрати території та формування нових держав, що не відповідає інтересам України при врегулюванні конфлікту на Донбасі.

\section{Бібліографічний список:}

1. Report of the Secretary-General on the United Nations transitional administration for Eastern Slavonia, Baranja and Western Sirmium. [Електронний pecypc]. ods.un.org/access.nsf/Get?Open\&DS=S/1997/767\&Lang=E.

2. Resolution 1145 (1997) Adopted by the Security Council at its 3843rd meeting. on 19 December 1997 S/RES/1145 (1997). [Електронний ресурс]. - Режим доступу: http:/undocs.org/en/S/RES/1145(1997).

3. Resolution 1272 (1999) Adopted by the Security Council at its 4057th meeting, on 25 October 1999. S/RES/1272 (1999). [Електронний ресурс]. - Режим доступу:http://undocs.org/en/S/RES/1272(1999). 
4. Security Council, 54th year: 4011th meeting, Thursday, 10 June 1999, New York, S/PV.4011. [Електронний pecypc]. - Режим доступу: http://daccess-ods.un.org/access.nsf/Get?Open\&DS=S/PV.4011\&Lang=E.

5. United Nations Transitional authority in Eastern Slavonia, Barnaja and Western Sirmium. [Електронний ресурс]. - Режим доступу: https://peacekeeping.un.org/ru/mission/past/untaes.htm.

DOI 10.31558/2617-0248.2018.3.8

УДК $327.5(73+540.1)$

\section{ІММІГРАЦІЯ В ПОРТУГАЛІЮ В ХХІ СТОЛІТТІ}

\section{Худолій А. О., А. політ. н., професор, професор кафедри міжнародних відносин Національного університету «Острозька академія» (Україна)}

У статті автор здійснив огляд міграційних процесів у Європі на початку XXI століття. Європейський Союз, як в цілому, так і кожна країна-член $\in C$, опинилися в складному становищі, майже на межі своїх можливостей в плані прийому та розміщення мігрантів. За останні роки XXI століття цей процес призвів не лише до нових проблем, але й загострив існуючі протиріччя, що виникли серед країн-членів Дублінської угоди в сфері розподілу переселенців з гарячих точок планети.

Здійснено спробу проаналізувати міграційні процеси в Португальській Республіці на початку XXI століття. Міграція $€$ досить складним і неоднозначним явищем, яке слід розглядати в кількох площинах: економічній, політичній, соціальній тощо. Серед кількох груп мігрантів домінуючими є бразильці та українці. Окрім вимушеним мігрантів, Португалія, значною мірою, приваблює трудових мігрантів. Домінуючими країнами-постачальними іммігрантів та, відповідно, робочої сили виступають Бразилія, Республіка Кабо-Верде та Україна. Слід зазначити, що в Португалії нараховують 412 тисяч іммігрантів, серед яких більше 100 тисяч бразильців і 42 тисячі українців. Щодо Бразилії, то міграція з цієї країни коріниться в історичних відносинах та двосторонніх зв'язках. 3 українцями ситуація інша, оскільки міграція до Португалії з України зумовлена економічними, політичними та соціальними чинниками.

У даній статті увага автора прикута до особливостей імміграції бразильців та українців до Португалії упродовж останніх п'ятнадцяти років. Виявлено та описано причини міграції двох найбільших груп іммігрантів. Виокремлено етапи імміграції в Португалію, починаючи з кінця XX століття. Автор виявив та описав типові проблеми іммігрантів, незалежно від етнічної приналежності. Окреслено перспективи українських іммігрантів у Португалії з урахуванням внутрішніх і зовнішніх чинників.

Ключові слова: міграція, імміграція, Португалія, ЄС, українські іммігранти, бразильські іммігранти.

Khudoliy A.O. Immigration to Portugal in the 21st Century.

The author made an observation of migration processes in Europe in the beginning of the 21st century. The European Union, in general and every state-member, in particular, is in dire straits, almost beyond their limits in terms of reception and deployment of migrants. Over the last years of the 21st century this process led not only to new problems, but also to certain contradictions among countries-members of the Dublin Regulation in the sphere of redistribution of migrants and asylum seekers from hot spots of the world.

The author of the article has made attempts to analyze migration processes in the Portuguese Republic in the beginning of the 21st century. Migration is rather complex and not trivial phenomenon which should be analyzed from different angles: economic, political, social etc. Among a few groups of migrants in Portugal the dominant ones are Brazilians and Ukrainians. Among forced migrants, Portugal attracts attention of labor immigrants. Among the dominant countries-sources of labor migrants are Brazil, the Republic of Cape Verde and Ukraine. It should be noted that, among 412 thousand immigrants living in Portugal, there are more than 100 thousand of Brazilians and 42 thousand of Ukrainians. Regarding Brazil, migration from this country is explained by historic development of the country and bilateral relations. With Ukrainians the situation is absolutely different, because migration to Portugal from Ukraine is due to economic, political and social factors. The article deals with characteristic features of immigration processes of Brazilians an Ukrainians in the Portuguese Republic in the last fifteen years of the twenty first century. The reasons for migration of the two most numerous groups of immigrants in Portugal are analyzed. Stages of migration to the Portuguese Republic since the end of the 20th century are identified and described. The author highlighted typical problems of immigrants despite the ethnic identification. Analysis of migration processes in Europe in the beginning of the twenty first century is being done. Perspectives of Ukrainian immigrants in Portugal along with inner and outer factors are depicted.

Key words: migration, immigration, Portugal, the EU, Ukrainian immigrants, Brazilian immigrants.

Bcmyn. Міграційні процеси, які спостерігаються в останнє десятиліття ХХІ століття спричинили значні зміни в багатьох сферах життя низки країн світу, як тих, з яких емігрують, так і тих, в які іммігрують. На жаль масштаби міграції збільшуються. 